\title{
ASSESSMENT OF THE RUSSIAN STRATEGY TO CONTRAST TERRORISM AND JIHADIST PROPAGANDA IN THE NORTH CAUCASUS
}

\author{
GIULIANO BIFOLCHI \\ giuliano.bifolchi@gmail.com \\ University of Rome Tor Vergata Department of History, Cultural Heritage, Education and Society \\ (Italy). Association of Studies, Research and Internationalization in Eurasia and Africa
}

Abstract

Terrorism, violent attacks and political Islam have affected the North Caucasus since the disintegration of the Soviet Union. If in the past the Caucasus Emirate was the leading terrorist organisation in the region since 2014 the Islamic State gained popularity and established the Vilayat Kavkaz (Caucasus Province) as part of the Caliphate exploiting the local critical socioeconomic condition and promoting the jihadist propaganda in the Russian language (i.e. the magazine 'Istok') also thanks to the considerable presence of North Caucasian foreign fighters among the ranks of Abu Bakr al-Baghdadi. Although currently the international coalition forces mainly defeated the Islamic State in Syria and Iraq, this organisation still jeopardises the North Caucasus often identified as the most volatile and impoverished area of the Russian Federation characterised by ethnic conflicts, the rise of Salafism, stagnation, and corruption. This study aims at stressing that the Russian government has elaborated a strategy mostly based on special military operations and massive investments in tourism and logistics which can exacerbate more the precarious status quo of the region favouring the dissemination of jihadist propaganda because it does not consider the historical, sociocultural, ethnic, and religious background. The region is not exempt to jihadist propaganda and terrorism and, if the Russian government cannot financially and economically support the regional leaders or will not change its approach, terrorism and political Islam could critically influence the North Caucasus posing a dangerous menace to the stability and security of the Russian Federation and entire Eurasia.

\section{Keywords}

North Caucasus, Russia, counterterrorism, security, Islam

How to cite this article

Bifolchi, Giuliano (2020). "Assessment of the Russian strategy to contrast terrorism and jihadist propaganda in the North Caucasus". In Janus.net, e-journal of international relations. Vol. 11, No. 2 Consulted [online] at date of last visit, DOI: https://doi.org/10.26619/1647$\underline{7251.11 .2 .2}$

Article received on July 20, 2019 and accepted for publication on February 26, 2020

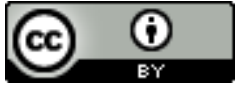




\title{
ASSESSMENT OF THE RUSSIAN STRATEGY TO CONTRAST TERRORISM AND JIHADIST PROPAGANDA IN THE NORTH CAUCASUS
}

\author{
GIULIANO BIFOLCHI
}

\section{Introduction}

The North Caucasus is a geopolitical strategic territory in the south of Russia that links Europe and Asia and splits the Christian and the Muslim worlds. Because of its geographic position and sociocultural background, the region has linkages with the Middle East, the Caspian Sea region, Central Asia, and the Arab-Muslim world. International superpowers (United States, Russia and China) and regional key players (Iran, Turkey, Azerbaijan, Georgia) are involved in the North Caucasian dynamics to control this interconnection centre and influence the international arena's development (Abtorkhanov \& Broxup, 1992; Bifolchi, 2018; Gazhiev, 2003, p. 44). The region is also a buffer zone which protects the south of Russia from an external military invasion and provides the Kremlin with access to the international maritime trade thanks to the Black Sea (Friedman, 2008).

After the disintegration of the Soviet Union, the North Caucasus has experienced interethnic conflicts, economic troubles, the rise of Salafism in contrast with the local Sufi community, terrorism, local militancy, unemployment, and corruption. Since the First Chechen Conflict (1994 - 1996) terrorism and local militancy have been the central regional issues: during the first decade of the $21^{\text {st }}$ century Imarat Kavkaz (Caucasus Emirate) was the local leading terrorist organisation while in 2014 the Islamic State gained popularity and created Vilayat Kavkaz (Caucasus Province) as part of the Caliphate exploiting the regional critical socio-economic situation and promoting the jihadist propaganda in the Russian language (i.e. the magazine 'Istok').

In 2010 the Russian Federation has elaborated and developed a counter-terrorism strategy based on military operations and extensive investments in tourism and logistics whose goals should have been pacifying the entire region, boosting the local socioeconomic development and contrasting terrorist recruitment among the young generations.

Although the Kremlin has emphatically described the positive impact of its strategy, terrorism is a threat in the North Caucasus and Imarat Kavkaz and Islamic State propaganda can still influence the local population because the Russian military forces have not yet wholly defeated the local jihadist groups. 


\section{Method of research and literature review}

This investigation seeks to demonstrate why the Kremlin's regional counter-terrorism strategy might only have a limited positive impact in the short-term on the North Caucasian security and stability without dealing with all the troubles which encourage the residents, principally the young generations, to join terrorist groups and the Islamist movement. If the Russian government cannot sustain the local leaders or will not adjust its strategy, terrorism and political Islam could badly interest the North Caucasus threatening the stability and security of the Russian Federation and entire Eurasia.

This paper reviews the academic literature on geopolitics, history, security, ethnography, and strategic communication as well NGO and media reports concerning the North Caucasus, terrorism in Russia and jihadist propaganda in the Russian language.

Academic scholars and regional experts often describe the North Caucasus as the Russian 'inner abroad' or 'domestic abroad' and they differentiate this region from the rest of the Russian Federation and the blizhnie zarubezhnye (near abroad) ${ }^{1}$ because of its peculiarities. Indeed, the North Caucasus has been described as 'a foreign region' in Russia where local tribal laws and Islam are more important in daily life than the Russian federal law. Due to its sociocultural, historical, and religious background, the ethnicRussians have often perceived the North Caucasus as a 'foreign' area inside the country closer to the Middle East and the Arab-Muslim world ( Halbach, 2010; Malashenko, 2011; 'Chechnya: The Inner Abroad', 2015;).

In terms of geopolitics, the North Caucasus plays a fundamental role in Russian domestic and foreign policy but at the same time, the region is one of the most destabilising elements of the Russian territorial sovereignty. Ethnocultural and ethnolinguistic problems, which have been characterised the region since the fall of the Soviet Union and the birth of the Russian Federation, have been used as instruments to foster conflict and interfere in the macro area Azov Sea - Black Sea - the Caspian Sea which Haushofer and Mackinder delineated as the world's most important areas of contrast. The United States - Russia confrontation still affects this macro area and, according to the concept of 'geopolitical axes' elaborated by Zbigniew Brzezinski, the White House started the prevention of Russian expansion to the south and towards the geopolitical pivots in the second decade of the $21^{\text {st }}$ century through the North Caucasus and the exploitation of ethnic, cultural, and religious differences as an element of instability (Avksentyev, 2016).

There is a general trend in Russian academic literature to underline the possibility that a foreign country, especially the United States, might exploit North Caucasian ethnic minorities and sociocultural problems to destabilise the Russian south, hence undermine the Kremlin's authority (Babayan, 2012; Eneev, 2014; Kolossov \& Sebentsov, 2014). The

\footnotetext{
The Russian term blizhnie zarubezhnye (Ближнее зарубежье) is the collective name of the former republics of the Soviet Union, now the Commonwealth of Independent States (CIS), as well as the Baltic republics (Latvia, Estonia, Lithuania), Ukraine, and Georgia. Among the countries referred to as "near abroad" there are those that do not have a common border with the Russian Federation (Armenia, Moldova, Turkmenistan, Tajikistan, Uzbekistan, Kyrgyzstan), while some states directly bordering on it do not include (Finland, Norway, Poland, Mongolia, PRC, DPRK). ROSSTAT refers to the near abroad the CIS countries except for Russia, referring to the far abroad Georgia, Abkhazia, South Ossetia, Transnistria, Nagorno-Karabakh and the Baltic countries, but this approach is not generally accepted.
} 
Russian concern over a US interference in the North Caucasian regional dynamics fits with what the US Intelligence agency Stratfor wrote about the region and the North Caucasian Muslim population defined as one of Russia's most vulnerable fronts (Goujon, 2016).

The North Caucasus is not only part of the geopolitical chessboard which opposes Russia and the West because the region is also the battleground where Russian security forces have fought local militants and terrorist groups. Indeed, since the disintegration of the Soviet Union independent movements and ethnonationalism have characterised the North Caucasus which during the '90s experienced the First Chechen War (1994-1996), the radicalisation of the Chechen cause and its transformation into a terrorist movement whose final purpose was to establish a North Caucasian emirate or imamate under the Islamic law and independent from the Russian central authority (Vendina et al., 2007).

Although the North Caucasian terrorism has its specific characteristics, it is not merely a regional phenomenon because local militancy and terrorism have affected the entire Russian soil and the North Caucasian jihadist groups have established some connections with the international terrorism network. The North Caucasian terrorism's roots belong to the radicalisation process and the spread of jihadist ideology started since the fall of the Soviet Union and increased during the Chechen struggle for independence against the Russian central authority during the First Chechen War when the entire country was facing the weakness of the national institutions, economic crisis, the rise of criminal activities, and an uncontrollable migrants flow (A. Yarlykapov, 2010).

\section{Terrorism in the North Caucasus}

Because of the Chechen conflict and the instability after the collapse of the Soviet Union the North Caucasus has experienced waves of radicalisation, militancy, terrorist attacks and the formation of jihadist groups (Pokalova, 2017).

In 2007 Doku Umarov created Imarat Kavkaz (Caucasus Emirate) whose aim was establishing an emirate in the North Caucasus based on shari'a law. The Caucasus Emirate organised some of the deadliest attacks in the entire Russian Federation and gained popularity among the local population (Roggio, 2007). Russian military forces and authorities perceived Imarat Kavkaz as the main threat for the national and regional security and their concern arose especially after the International Olympic Committee the Russian Federation as the hosting country of the 2014 Winter Olympic Games in Sochi. It is possible to underline a connection between Sochi 2014 and Imarat Kavkaz's decline because of a major military involvement and activity of the Russian special forces in the North Caucasus in the years 2013-2015 that allowed the elimination of Doku Umarov and the most representative leaders of the organisation (Hann, 2014; 'Imarat Kavkaza /Caucasus Emirate', 2014; Jasutis, 2016).

While the Russian special forces were eliminating some of the most influential leaders of the Caucasus Emirate, the Islamic State started gaining popularity in the North Caucasus. In 2014 some Imarat Kavkaz's leaders pledged allegiance to Abu Bakr al-Baghdadi opening the door of the region to the Islamic State which created Vilayat Kavkaz (Caucasus Province) as a part of the 'new Caliphate' (Borshchevskaya, 2015; Flood, 
2015). The creation of Vilayat Kavkaz in the North Caucasus might be the conclusion of a process consisted in the dissemination of jihadist propaganda in the Russian language through the magazine 'Istok' and Social media accounts to promote ISIS ideology and recruit foreign fighters in the post-Soviet space. In reality, according to Russian President Vladimir Putin, around a 4,000 - 5,000 Russian nationals have joined the Islamic State and among them, there was a considerable group of North Caucasians (North Caucasian Fighters in Syria and Iraq \& IS Propaganda in Russian Language, 2015; Parazsczuk, 2015).

Since 2010, the North Caucasus has registered a significant decrease in violent attacks and terrorist activities although the region is not immune to jihadist propaganda and militancy. Considering the data reported by Kavkaz Uzel, during the period 2010-2017 the North Caucasus recorded 6,536 violent attacks: Dagestan, Chechnya and Ingushetia were the republics most affected by terrorism followed by Kabardino-Balkaria, NorthOssetia-Alania, Stavropol Krai and Karachay-Cherkessia. During these seven years, the number of fatalities dropped from 1,705 in 2010 to 175 in 2017.

In 2018, Dagestan registered most violent attacks in the North Caucasus although the total number of victims decreased by 10.9 per cent compared with 2017. Among the 49 people involved in regional violence, the militants had the main casualties (Chislo Zhertv Vooruzhennogo Konflikta v Dagestane Za 2018 God Sokratilos' Pochti Na 11\%, 2019).

The Chechen Republic was not immune from violence even though the Kremlin has promoted the country as its success in counterterrorism: in 2018, 26 people were killed and nine injured. Compared to 2017 (75 victims), the total number of victims diminished by 53.3 per cent but the number of armed incidents increased by 37.5 per cent (Chislo Zhertv Konflikta Na Territorii Chechni Umen'shilos' Na Fone Aktivizacii Boevikov v 2018 Godu, 2019). The third most-violent republic in the North Caucasus was Ingushetia which reduced the number of victims by 58 per cent even though the local government could not avoid violent attacks that caused ten victims, eight people killed and two wounded (Chislo Zhertv Vooruzhennogo Konflikta v Ingushetii Za 2018 God Snizilos' Na 58\%, 2019).

In Stavropol Krai, violent attacks resulted in six people killed and two wounded. The North Caucasian republic experienced an increase of victims of 33.3 per cent in comparison with the 2017 (Chislo Zhertv Vooruzhennogo Konflikta Za 2018 God Na Stavropol'e Vyroslo $\mathrm{Na} 33,3 \%, 2019)$. Last year, in the territory of Kabardino-Balkaria, six people became victims of the ongoing armed conflict between the local militants and the authorities. The number of victims in the republic was 500 per cent more than in 2017 when only one person was killed (Za 2018 God Chislo Zhertv Konflikta v KabardinoBalkarii Vyroslo Na 500\%, 2019). North Ossetia-Alania was immune to terrorist attacks showing its success in de-radicalisation and security. If in 2018 the republic did not experience any form of violent attacks, in 2017 four-armed incidents caused the death of five people and four injured (Severnaja Osetija v 2018 Godu Vernula Poziciju Mirnogo Regiona $v$ Zone Vooruzhennogo Konflikta, 2019). Also in Karachay-Cherkessia, there were no victims in 2018, a positive trend compared to the five people killed in 2017 because of the armed conflict (Zhertv Vooruzhennogo Konflikta $v$ Karachaevo-Cherkesii v 2018 Godu Ne Bylo, 2019). 
In the first quarter of 2019 , at least 21 people (16 killed and five wounded) were victims of violent attacks and terrorism in the North Caucasus. Kabardino-Balkaria was the North Caucasian republic mostly affected followed by Dagestan, Ingushetia, Stavropol Krai and Chechnya ("Infografika. Statistika zhertv na Severnom Kavkaze v pervom kvartale 2019 goda po dannym Kavkazskogo Uzla," 2019).

\section{The confrontation between the 'traditional official Islam' and the emerging Salafism}

The Russian central authority considers necessary improving security in the region and pays predominantly attention to military operations and the total number of victims. Even though the coexistence between Sufi and Salafi communities has generated confrontation and a new wave of violence and radicalisation, Moscow and local governments seem to underestimate this problem whose roots belong to the dissolution's period of the Soviet Union when the North Caucasus experienced an 'Islamic revival' and Islam gave its contribution to the new regional identity after the failure of the Soviet ideology. During the '70s and the '80s and after the collapse of the USSR young generations of Muslims travelled to the Middle East, the Gulf and North Africa aiming at receiving an education in Islam orthodoxy and practices in the local madrasa or the most prestigious institutions in the Muslim world to fill the lack of Muslim religious figures and knowledge which the North Caucasus experienced because of the 'Sovietisation', the 'Russification' and the Kremlin's anti-religion campaign during the Soviet times. Simultaneously, Muslim scholars and imams from the Middle East, the Gulf and North Africa arrived in the region supporting the 'religious re-birth' and promoting what they considered the 'real Islam' based on the ideologies of the Muslim Brotherhood, Salafism, Wahhabism, and Hizb ulTahrir. These scholars, supported by their governments, established a network of associations and organisations involved in financing social projects, building new mosques and recruiting future students for their madrasa (Berezhnoj et al., 2003; A. Yarlykapov, 2010; A. A. Yarlykapov, 2015).The ideological Islamic propaganda promoted by foreign countries and those young Muslims who studied abroad generated the spread of radical Islam in the North Caucasus during the '90s when the region was facing the Chechen independence conflict between Grozny and Moscow and local interethnic conflicts such as that in the eastern Prigorodny inherited from the Tsarists and Soviet past administration. Hence, the region started soon experimenting with the rise of jihadi Salafi ideology often labelled by the Russian government and state media as 'Wahhabism'. Sunni extremist local armed groups engaged in the fight against the Russian central authority adopted this ideology as their framework (Chifu, 2011; Sagramoso, 2012; Sokirianskaia, 2007).

The spread of new ideologies, the rise of Salafism and terrorist groups caused a confrontation between supporters of the 'traditional official Islam' (Sufi) and the new generation of Muslims (Salafi) which sharply aggravated the security situation and the cohabitation in the North Caucasus. Each North Caucasian republic (particularly in the eastern part of the region) has registered different trends and peculiarities and there is a non-homogeneous strategy regarding the rise of Salafism and the support to Sufism (Abdulagatov, 2013; V. Akaev, 2008; V. H. Akaev, 2010; Makarkin, 2016): 
In Chechnya, there is a conflict between traditional Sufism sustained by the local authorities and Salafism of the young generations promoted as the 'only real Islam' and purified by local traditions (for instance ziyāra). After the process of 'Chechenisation' adopted by the Kremlin to overcome the problems caused by the conflict and start the reconstruction process, the Chechen leader Ramzan Kadyrov started the 'Islamisation' of the Chechen society supporting Sufism and fighting against any form of Salafism (Chechnya Encourages Islamic-Style Customs, 2011; Vatchagaev, 2014; Barak, 2016).

- $\quad$ In Dagestan, the Salafists are against the tukhum (tribal clan identity) and the 'ādāt (tribal law), and they accept only the Muslim umma as a central element of their lives. The rise of Salafism in Dagestan caused a clash with the 'traditional official Islam' (Sufism) because of different views regarding the role of the tribal code in religion. In fact, while the Sufi community considers vital the ethnic element, the 'new Islam' (Salafism) aims at establishing a society purified by ethnicity and based only on religion. Also, there is a struggle for control over the mosques where Salafists pray because the Salafi community plays an important role in the country ( Rozanova-Smith \& Yarlykapov, 2014; Roshchin, 2018).

- $\quad$ The new generations of Muslims from Kabardino-Balkaria who studied in the Middle East and the Gulf clashed with the local authorities regarding the concept of 'real Islam' and 'traditional Islam'. In 2005, an armed Salafi group organised an attack in Nalchik (capital of Kabardino-Balkaria) causing 130 victims and over 200 injured people. In March 2010 the Russian security forces killed Anzor Astemirov, leader of the militant movement (Salafi), exacerbating the confrontation between Sufi and Salafi communities and the Salafists with the local government. This hostility is at the base of the spread of jihadist propaganda and Islamic State recruitment in the North Caucasian Republic (Hahn, 2005; Fagan, 2014).

- In Ingushetia, the confrontation between Sufi and Salafi Muslims has involved Issa Khamkhoev, the leader of the national muftiate or Dukhovniy Zentr Musul'man Respubliki Ingushetii (Spiritual Centre of Muslims of the Republic of Ingushetia, DZM) and a member of the Qãdiriyya Brotherhood, Khamzat Chumakov, since 2008 the Salafi imam of the mosque of the village Nasir-Kort in the city of Nazran who survived at three different killing attempts and resigned from his position in 2018, and Yunus-Bek Yevkurov who, since he was appointed the head of the Ingush Republic, has adopted a domestic policy based on military operations against the local Islamist rebel groups, open dialogue with the local Salafi communities and an attempt to promote a de-radicalisation process (Kvakhadze, 2018; Ramazanov, 2018).

\section{Russian counter-terrorism strategy}

Since the creation of the North Caucasus Federal District in 2010, the Kremlin has elaborated a strategy based on Kontrterroristicheskoj Operacii (counter-terrorism operations, KTO) against local militants and those people accused of being terrorists or linked to the terrorist network, the adoption of national, federal and local laws against terrorism, political Islam, religious extremism and 'Wahhabism', and a socio-economic 
development programme to improve the regional living conditions and open the North Caucasus to foreign direct investments (FDIs).

Socioeconomic development has relied on the administrative reorganization of the region and a strategy based on tourist and logistics clusters. On January 19, 2010, President Dmitri Medvedev signed the decree N.82 which created the Severo-Kavkazskij Federal'nyj Okrug (North Caucasus Federal District, NCFD), separated the North Caucasus by the Juzhnyj Federanlij Okrug (Southern Federal District, SFD) where the Kremlin organized Sochi 2014, and launched the "Strategija Socianl'noJekonomicheskovo Razvitija Severo-Kavkazkovo Federal'novo Okruga do 2025" (Strategy of Socioeconomic Development of the NCFD until 2025, Strategy 2025) to contrast the economic problems and improve the local living conditions. On October 14, 2010, Prime Minister Vladimir Putin signed the decree N. 833 "O sozdanii turisticheskovo klastera $v$ Severo-Kavkazskom federal'nom okruge, Krasnodarskom krae i Respublike Adygeja" (On tourism cluster creation in the North Caucasus Federal District, the Krasnodar Kray and the Republic of Adygea) which established a tourism cluster in the NCFD, Krasnodar Krai and Adygea.

On December 2, 2010, the decree N. 833 instructed the AO 'Kurortiy Severnovo Kavkaza' (Open Joint-Stock Company Northern Caucasus Resorts, JSC NCR) to manage the tourism and recreational special economic zones in the NCFD with the purpose of designing, constructing and commissioning new ski resorts to attract FDIs and international tourist flow and transform the North Caucasus as one of the leading destinations in recreational tourism. The last action of the Russian central authority in the North Caucasus was on May 12, 2014, when President Vladimir Putin signed the decree N. 636 to establish the Ministerstvo po Delam Severnovo Kavkaza (Ministry of the North Caucasus' Affairs, Minkavkaz).

Thanks to this administrative configuration and economic plan the Kremlin aimed at improving socio-economic conditions in the region, boosting the economic development, providing around 400 thousand jobs to the locals, attracting FDIs, connecting the region with the most important commercial routes, and contrasting the North Caucasian jamā'at (terrorist groups) and their recruitment activities (Vatchagaev, 2011; Tappaskhanova et al., 2015).

\section{Conclusions}

Although the Russian government has heavily financed the North Caucasians republics, the NCFD risks remaining one of the most unstable Russian regions and one of the predominant threats to national security and stability. The strategy to focus every effort on economic development without considering local peculiarities, the historical background, and the current negative feelings of the population that always see the contraposition between russkij and russiyane might become the biggest mistake of the Russian government in managing ethnic minorities in the region.

The ethnic Russians have always seen the North Caucasus as a challenging area, and during the centuries they have developed popular feelings against non-ethnic Russians, especially toward the North Caucasian people. Kavkazofobija (the fear of the Caucasus) 
is a negative feeling of the Russian society toward the North Caucasians fueled by the two Chechen wars, the local insurgency and the waves of terrorist attacks on the Russian soil. Kavkazofobija resulted in the slogan 'xvatit kormit Kavkaz' (stop feeding the Caucasus) often used in the Russian political discourse to accuse the Kremlin of financing massive regional investment projects using State funds (Bifolchi, 2019). In his research, Andrew Foxall showed that the mass riots against the North Caucasians in Kondopoda (2006), Stavropol (2007), Moscow (2010 and 2013), and Pugachyov (2013) exacerbated the confrontation with the ethnic-Russians. This climate of fear infusing disappointment and distrust among the North Caucasians who do not consider themselves part of the Russian society and look at the Islamist cause and the local militancy as the solution of their problems (Foxall, 2014).

In the NCFD there are no direct elections of regional leaders appointed by the Kremlin. The lack of a democratic process alienates the local population from political life and generates mistrust regarding the authorities (The North Caucasus: The Challenges of Integration (III), Governance, Elections, Rule of Law, 2013). In the NCFD there are two main trends about the governance strategy based on their centralization: the first one is that of Chechnya where Kadyrov does not have direct political opposition, manages the most significant business activities, and bases the economic development of his country on federal subsidies and development programs whose purpose is to improve the level of security and boost the economic recovery. The second model of governance could be that of Karachay-Cherkessia or Dagestan where the head of the republic emerges from an agreement between the different ethnic groups which fight for access to the financial state subsidies.

Even though in the last years the security level in the region has increased thanks to KTO and the Kremlin's socioeconomic strategy, the North Caucasus is not a safe and stable region as the Russian government promoted because the jihadist propaganda has proved that can influence the local population, especially the young generations, and a threat both the locals and the authorities (Falkowski, 2014).

Besides, in the North Caucasus life and cohabitation between different ethnic and religious groups has not improved. Nowadays, ethnic and religious tensions are at the base of socioeconomic problems. Certainly, the North Caucasus is a multi-ethnic region and every approach to contrast terrorism and manage the local republics should consider the historical and socio-cultural background and the distinctive peculiarity of every ethnic group (The North Caucasus: The Challenges of Integration (I), Ethnicity and Conflict, 2012).

These feelings of distrust regarding the central authority mixed with ethnic tensions, the struggle for the land, and the lack of job opportunities are the reasons of the growing importance of Salafism which offers a virtuous Islamist state based on shari'a law as an alternative model. Hence, Islamic State and the Caucasus Emirate are still the major threats to the stability and security of the region because the young generations disbelieve the local government and policies which have given no solutions to improve their socioeconomic status and prefer to join the Islamist cause.

Economic development is fundamental in the North Caucasus, but it significantly depends on the Russian state budget and the national economic performance. Thus, an economic 
crisis in the Russian Federation, as that the country experienced in the past years due to the falling oil prices, might affect the North Caucasian security and social situation because the region is still unable of attracting FDIs and the attention of the Russian businessmen. Foreign and Russian entrepreneurs are reluctant to take part in North Caucasian economic development because they consider the region volatile and not profitable. This makes the North Caucasian republics dependent on the Kremlin's financial subsidies and the State budget. Undeniably, the regional situation is complicated and presents two different realities: on the one hand, the persisting high level of poverty and unemployment might push some people, especially young adults, toward Islamist cause and radicalism. On the other hand, local investors and elites do not have the stimulus and the reasons to invest money and efforts to improve the regional socio-economic development and maintain the social order, mainly after Moscow lost its ability to support local governments (Kazenin \& Starodubrovskaya, 2015).

In conclusion, the Russian Federation needs to control the North Caucasus because of its geopolitical and strategic role, but the Kremlin must elaborate a sociocultural - economic strategy to contrast terrorism and jihadist propaganda. When the Islamic State will be completely defeated in the MENA region there is the risk that the North Caucasian foreign fighters might come back home, apply guerrilla tactics and promote jihadist ideology in the region threatening the local security and ruining the Kremlin's socioeconomic development strategy focused on tourist clusters(Hedenskog \& Holmquist, 2015; The North Caucasus Insurgency and Syria: An Exported Jihad?, 2016).

The Russian policy should assess ethnic and religious groups to avoid that tensions will explode in local conflicts, and the Islamist cause will spread among the young generations. Even though the creation of the NCFD, Minkavaz and the Strategy 2025 might be a starting point, especially in economy, the North Caucasus needs an approach more oriented on decreasing the use of violence by military forces and local police whose primary goal should fight corruption.

It is fundamental to establish free electoral processes that allow the indigenous population to elect their representatives and head of state and guarantee accountability and transparency to government. Regarding the local society, improving the quality of life through health-care investments and supporting the role of education are one of the primary tools in the region's integration and conflict management.

Also, Russia should be more engaged in a dialogue with the Salafi communities trying to avoid a confrontation between the 'traditional local Islam' represented by Sufism and the Salafists and distinguishing between jihadi Salafism and Salafism. Therefore, Salafists feel persecuted by the local authorities supported by the Sufi leadership, while Sufis feel themselves in danger because Salafi jihadist groups identify them as potential targets.

Security and stability in the North Caucasus are also a concern for the European Union because the region plays a strategic role in the Eurasian continent. Although the Ukrainian Crisis froze the cooperation between Moscow and Brussels in counterterrorism and de-radicalization, it is advisable a decisive involvement of the European countries in the region through investments and exchanges of good practices in contrasting terrorism and managing ethnic minorities. Otherwise, the destabilisation of the North Caucasus risks to threaten the security of entire Europe and might create a logistics hub for jihadist 
and terrorist groups to spread their ideologies and organize violent attacks in the entire continent.

\section{References}

Abdulagatov, Z. M. (2013). Islamskoe massovoe soznanie na Severnom Kavkaze XXI v.: Dagestan, Kabardino-Balkariya, Chechnya. Pax Islamica, 2(11), 138-159.

Abtorkhanov, A., \& Broxup, M. B. (1992). The North Caucasus Barrier: The Russian Advance Towards the Muslim World. Palgrave Macmillan.

Akaev, V. (2008). Conflicts between Traditional and Non-Traditional Islamic Trends: Reasons, Dynamics, and Ways to Overcome Them (based on North Caucasian documents). Central Asia and the Caucasus, 2(50), 108-116.

Akaev, V. H. (2010). Religiozno-politicheskie Osobennosti «Severokavkazskogo Vahhabizma» i Konflikt s Sufizmom. Islamovedenie, 4, 4-17.

Avksentyev, V. (2016). Ethnocultural and Ethnoreligious Problems as Instruments of Geopolitics. Nauchnyj Al'manah Stran Prichernomor'ja, 3(7), 6-11.

Babayan, D. (2012). Severnyi Prikaspij na Geopoliticheskoj Povestke KNR. Central'naja Azija i Kavkaz, 15(3), 63-77.

Barak, M. (2016, November 9). The Grozny Conference in Chechnya - Is the Salafi Movement a Rotten Fruit of Sunni Islam? International Institute for Counter-Terrorism (ICT). https://www.ict.org.il/Article/1808/the-grozny-conference-in-chechnya-is-thesalafi-movement-a-rotten-fruit-of-sunni-islam\#gsc.tab $=0$

Berezhnoj, S. E., Dobaev, I. P., \& Krajnjuchenko, P. V. (2003). Islam i Islamizm na Juge Rossi.

Bifolchi, G. (2018). Panorama Geopolitico del Mundo Actual: Geopolítica del Cáucaso del Norte en clave . Didácticas Especificas, 19, 112-119.

Borshchevskaya, A. (2015). The IslamIc State Comes To Russia. The Journal of International Security Affaris, 27-32.

Chechnya: The Inner Abroad. (2015). In Europe Report (Issue 236). International Crisis Group.

Chechnya Encourages Islamic-Style Customs. (2011, February 20). The Moscow Times. Independent News From Russia. https://www.themoscowtimes.com/2011/02/20/chechnya-encourages-islamic-stylecustoms-a5138

Chifu, I. (2011). Religion and Conflict: Radicalism and Violence in the North Caucasus. Turkish Policy Quarterly, 10(3), 121-132.

Chislo zhertv konflikta na territorii Chechni umen'shilos' na fone aktivizacii boevikov $v$ 2018 godu. (2019, January 26). Kavkaz Uzel. https://www.kavkazuzel.eu/articles/330852/

Chislo zhertv vooruzhennogo konflikta v Dagestane za 2018 god sokratilos' pochti na 
11\%. (2019, February 1). Kavkaz Uzel. https://www.kavkaz-uzel.eu/articles/331120/

Chislo zhertv vooruzhennogo konflikta v Ingushetii za 2018 god snizilos' na 58\%. (2019, February 6). Kavkaz Uzel. https://www.kavkaz-uzel.eu/articles/331318/

Chislo zhertv vooruzhennogo konflikta za 2018 god na Stavropol'e vyroslo na 33,3\%. (2019, January 28). Kavkaz Uzel. https://www.kavkaz-uzel.eu/articles/330930/

Eneev, D. O. (2014). Interesy Zapadnyh stran na Severnom Kavkaze kak ugroza nacional'noj bezopasnosti RossiiV. Internet-Zhurnal «NAUKOVEDENIE», 3, 1-10.

Fagan, G. (2014). A word of justice: Islam and state repression in the North-West Caucasus. Central Asian Survey, 33(1), 29-46. https://doi.org/10.1080/02634937.2013.826441

Falkowski, M. (2014). On the Periphery of Global Jihad. The North Caucasus: the Illusion of Stabilisation.

Flood, D. H. (2015). The Islamic State Raises Its Black Flag Over The Caucasus Combating Terrorism Center at West Point. CTC Sentinel, 8(6), 1-4.

Foxall, A. (2014). Ethnic relations in post-Soviet Russia: Russians and non-Russians in the North Caucasus. In Ethnic Relations in Post-Soviet Russia: Russians and NonRussians in the North Caucasus. Taylor and Francis Inc. https://doi.org/10.4324/9781315754246

Friedman, G. (2008). The Geopolitics of Russia: Permanent Struggle.

Gazhiev, K. (2003). Geopolitika Kavkaza. Mezhdunarodnye Otnoshenija.

Goujon, R. (2016, February 16). Ruthless and Sober in Syria. Stratfor. https://worldview.stratfor.com/article/ruthless-and-sober-syria

Hahn, G. M. (2005). The rise of Islamist extremism in Kabardino-Balkariya. Demokratizatsiya, 13(4), 543-594. https://doi.org/10.3200/DEMO.13.4.543-594

Halbach, U. (2010). Russia's Internal Abroad. The North Caucasus as an Emergency Zone at the Edge of Europe. In SWP Research Paper. Stiftung Wissenschaft und Politik.

Hann, G. M. (2014). The Caucasus Emirate Mujahedin: Global Jihadism in Russia's North Caucasus and Beyond (9780786479528): Gordon M. Hahn: Books. McFarland \& Company.

Hedenskog, J., \& Holmquist, E. (2015). The threat of the Islamic State to Russia's North Caucasus and Central Asia (No. 28; RUFS Briefing).

Imarat Kavkaza /Caucasus Emirate. (2014). In IHS Jane's World Insurgency \& Terrorism. Jasutis, G. (2016). The Rise and Decline of the Caucasus Emirate by Grazvydas Jasutis (Issue 9).

Kazenin, K., \& Starodubrovskaya, I. (2015). North Caucasus: The New Management Model and Old Problems. In Russia Economy in 2014. Trends and Outlooks (Issue 36). Gaidar Institute for Economic Policy; Russian Presidential Academy of National Economy and Public Administration (RANEPA) - Center for Regional Studies and Urban Studies.

Kolossov, V., \& Sebentsov, A. (2014). Severnyj Kavkaz v Rossijskom Geopoliticheskom 
Diskurse. Polis. Politicheskie Issledovanija. Politicheskie Issledovanija, 2, 146-163. https://doi.org/10.17976/jpps/2014.02.11

Kvakhadze, A. (2018). Local Muslim Spiritual Leaders Excommunicate Head of Ingushetia - Jamestown. Eurasia Daily Monitor, 15(91).

Makarkin, A. (2016, February 8). Severnyj Kavkaz: Sufii vs. Salafity. Politikom.Ru. http://politcom.ru/20699.html

Malashenko, A. V. (2011). The North Caucasus: russia's Internal Abroad? In Briefing (Vol. 13, Issue 3). Carneie Moscow Center.

North Caucasian fighters in Syria and Iraq \& IS propaganda in Russian language. (2015).

Parazsczuk, J. (2015, July 13). Isis launches Russian-language propaganda channel. The Guardian. https://www.theguardian.com/world/2015/jul/13/isis-russia-caucasuschechnya-syria-progaganda-channel

Pokalova, E. (2017). The North Caucasus: from mass mobilization to international terrorism. Small Wars and Insurgencies, 28(3), 609-628. https://doi.org/10.1080/09592318.2017.1307615

Ramazanov, R. O. (2018). Osobennosti islamistskogo radikalizma na Severnom Kavkaze (na primere Dagestana). Theories and Problems of Political Studies, 7(5A), 193-202.

Roggio, B. (2007, November 26). Doku Umarov declares Islamic Caucasus Emirate. FDD's Long War Journal. https://www.longwarjournal.org/archives/2007/11/doku_umarov_declares.php

Roshchin, M. (2018, April 15). Islamist Movements in Dagestan and North Ossetia - AlMesbar Center. Al Mesbar Studies \& Research Center. https://mesbar.org/islamistmovements-in-dagestan-and-north-ossetia/

Rozanova-Smith, M., \& Yarlykapov, A. (2014). The Islamic Religion and Cultural Diversity in Contemporary Russia: Case Study of North Caucasus Region, Dagestan. OMNES: The Journal of Multicultural Society, 5(1), 22-47.

Sagramoso, D. (2012). The Radicalisation of Islamic Salafi Jamaats in the North Caucasus: Moving Closer to the Global Jihadist Movement? Europe - Asia Studies, 64(3), 561-595. https://doi.org/10.1080/09668136.2012.661933

Severnaja Osetija v 2018 Godu Vernula Poziciju Mirnogo Regiona v Zone Vooruzhennogo Konflikta. (2019, January 29). Kavkaz Uzel. https://www.kavkazuzel.eu/articles/330943/

Sokirianskaia, E. (2007). Ideology and conflict: Chechen political nationalism prior to, and during, ten years of war. In M. Gammer (Ed.), Ethno-Nationalism, Islam and the State in the Caucasus: Post-Soviet Disorder (pp. 111-124). Routledge.

Tappaskhanova, E. O., Mustafayeva, Z. A., Ligidov, R. M., \& Kudasheva, N. Z. (2015). Development of Innovative Business in the Industry Tourism as the Most Important Factor of Employment of Youth in North Caucasian Federal District. International Business Management, 9(7), 1668-1678.

The North Caucasus: the Challenges of Integration (I), Ethnicity and Conflict (No. 220; 
Europe Report). (2012). International Crisis Group.

The North Caucasus: The Challenges of Integration (III), Governance, Elections, Rule of Law (No. 226; Europe Report). (2013).

The North Caucasus Insurgency and Syria: An Exported Jihad? (No. 238; Europe Report). (2016).

Vatchagaev, M. (2011). Plans To Build North Caucasus Ski Resorts: Why Paint The Fence If The House Is Burning? . North Caucasus Weekly, 12(19).

Vatchagaev, M. (2014). The politicization of Sufism in Chechnya. Caucasus Survey, 1(2), 25-35. https://doi.org/10.1080/23761199.2014.11417294

Vendina, O. I., Belozerov, V. S., \& Gustafson, A. (2007). The wars in Chechnya and their effects on neighboring regions. Eurasian Geography and Economics, 48(2), 178-201. https://doi.org/10.2747/1538-7216.48.2.178

Yarlykapov, A. (2010). The Radicalization of North Caucasian Muslims. In R. Dannreuther \& L. March (Eds.), Russia and Islam: State, Society and Radicalism (pp. 137-154). Routledge.

Yarlykapov, A. A. (2015). Islam na Kavkaze i eo Vlijanie na Konfliktnost" $v$ Regione i Rossii. Comparative Politics (Russia), 4(3(13)), 133. https://doi.org/10.18611/22213279-2013-4-3(13)-133-152

Za 2018 God Chislo Zhertv Konflikta v Kabardino-Balkarii Vyroslo na 500\%. (2019, February 19). Kavkaz Uzel. https://www.kavkaz-uzel.eu/articles/331639/

Zhertv Vooruzhennogo Konflikta v Karachaevo-Cherkesii v 2018 Godu ne Bylo. (2019, January 29). Kavkaz Uzel. https://www.kavkaz-uzel.eu/articles/330942/ 